\title{
HES3 wt Allele
}

National Cancer Institute

\section{Source}

National Cancer Institute. HES3 wt Allele. NCI Thesaurus. Code C104531.

Human HES3 wild-type allele is located in the vicinity of $1 \mathrm{p} 36.31$ and is approximately $1 \mathrm{~kb}$ in length. This allele, which encodes transcription factor HES-3 protein, is involved in the negative regulation of transcription. 